\title{
Absorption of Medium and Long Chain Triglycerides: Factors Influencing Their Hydrolysis and Transport*
}

\author{
Norton J. Greenberger, $†$ John B. Rodgers, and Kurt J. Isselbacher $\ddagger$ \\ (From the Department of Medicine, Harvard Medical School, and the Medical Services \\ [Gastrointestinal Unit], Massachusetts General Hospital, Boston, Mass.)
}

Recent clinical observations have indicated that triglycerides containing medium chain fatty acids may be useful in decreasing steatorrhea associated with malabsorptive states such as pancreatic insufficiency and extrahepatic biliary tract obstruction $(1,2)$. This suggests that significant amounts of medium chain triglycerides may be absorbed under conditions in which there are decreased intraluminal concentrations of pancreatic enzymes or bile salts. However, few quantitative data are available regarding the intestinal hydrolysis and the rate of absorption of medium chain triglycerides as compared to long chain triglycerides.

We have compared the intestinal hydrolysis and absorption of a medium chain triglyceride (trioctanoin) with those of a long chain triglyceride (tripalmitin) under a variety of experimental conditions. These studies were performed with isolated intestinal loops in the rat.

The data obtained indicate that there are significant differences in the rates of hydrolysis and absorption of trioctanoin compared to tripalmitin. We also observed that with decreased intraluminal concentrations of bile salts and pancreatic enzymes there was, as expected, decreased absorption of both trioctanoin and tripalmitin. However, under

* Submitted for publication July 29, 1965 ; accepted October 29, 1965.

This work was supported in part by grants from the John A. Hartford Foundation, Inc., and the National Institutes of Health (AM-01392, 03014, and T1-AM5146).

Part of this work was presented at the annual meeting of the American Federation for Clinical Research, Atlantic City, N. J., May 2, 1965, and appears in abstract form in Clin. Res. 1965, 13, 253.

$\dagger$ Part of this work was done during the tenure of a U. S. Public Health Service fellowship (1F3-AM-24, 750-01). Current address : Dept. of Medicine, Ohio State University, Columbus, Ohio.

$\ddagger$ Address requests for reprints to Dr. Kurt J. Isselbacher, Massachusetts General Hospital, Boston, Mass. 02114. these conditions there was significantly less impairment in the absorption of trioctanoin. We also performed studies utilizing agents that inhibit protein synthesis and demonstrated additional differences in the absorption and transport of trioctanoin and tripalmitin.

\section{Methods}

Preparation and measurement of ${ }^{14} \mathrm{C}$-labeled lipid substrates. Sodium octanoate- $1-{ }^{14} \mathrm{C}$ and sodium palmitate${ }^{1-{ }^{14}} \mathrm{C}^{1}$ were converted to the free fatty acid and along with tripalmitin-carboxy1-14 $\mathrm{C}$ and trioctanoin-carboxyl- ${ }^{16} \mathrm{C}$ were purified by thin layer chromatography. The developing solvent system used for the palmitic acid and tripalmitin contained by volume $84.5 \%$ petroleum ether, $14 \%$ diethyl ether, and $1.4 \%$ glacial acetic acid. The solvent system for octanoic acid and trioctanoin contained by volume $57 \%$ hexane, $41 \%$ diethyl ether, and $2 \%$ glacial acetic acid. All ${ }^{14} \mathrm{C}$-labeled lipids used in these experiments were $98 \%$ pure. The fatty acid and triglyceride substrates were dissolved in a small amount of ether and homogenized in $10 \%$ crystalline albumin with subsequent evaporation of the ether. Nonradioactive lipid carrier was added before homogenization so that the final concentration of the various lipid-albumin suspensions was either 5 or $10 \mu$ moles lipid per $\mathrm{ml}$.

Samples of the various ${ }^{14} \mathrm{C}$-labeled lipid-albumin suspensions were added to $12 \mathrm{ml}$ of a solution of $p$-dioxane containing $5 \%$ naphthalene, $0.01 \% p$-bis- $2^{\prime}-\left(5^{\prime}\right.$-phenyloxazolyl)benzene, $0.7 \% \quad p$-bis-2,5-diphenyloxazole, and $13.3 \%$ absolute ethanol and were counted in a Packard Tri-Carb liquid scintillation spectrometer. The solution prepared for counting substances in organic solvents contained $15 \mathrm{ml}$ of toluene with $4.0 \%$ Liquifluor. ${ }^{2}$ Quenching was corrected for by utilizing a standard quenching curve as described by Bush (3).

Experiments on lipid absorption from isolated intestinal loops. With female rats weighing 160 to $180 \mathrm{~g}$ under light ether anesthesia, a laparotomy was performed, and a 20 - to $30-\mathrm{cm}$ segment of the lower duodenum and jejunum was isolated between double silk ligatures, care being taken not to obstruct the blood flow. In experiments in which normal intestinal loops were utilized, the proximal ligature was placed at the pyloroduodenal

1 New England Nuclear Corp., Boston, Mass.

2 Pilot Chemicals, Watertown, Mass. 
TABLE I

Hydrolysis of ${ }^{14} \mathrm{C}$-labeled lipids in isolated intestinal loops

\begin{tabular}{|c|c|c|c|c|c|c|c|}
\hline \multirow{2}{*}{$\begin{array}{l}\text { Lipid-14C } \\
\text { substrate* }\end{array}$} & \multirow{2}{*}{$\begin{array}{l}\text { No. } \\
\text { experi- } \\
\text { ments }\end{array}$} & \multirow{2}{*}{$\begin{array}{l}\text { Type } \\
\text { loop }\end{array}$} & \multirow{2}{*}{$\begin{array}{l}\% \text { of dose re- } \\
\text { covered in } \\
\text { loop contents } \\
(15 \text { minutes })\end{array}$} & \multirow{2}{*}{$\begin{array}{c}\text { Fatty } \\
\text { acid }\end{array}$} & \multicolumn{3}{|c|}{ Glyceridest } \\
\hline & & & & & TG & DG & MG \\
\hline $\begin{array}{l}\text { Trioctanoin } \\
\left(10 \times 10^{6} \mathrm{dpm},\right. \\
5 \mu \text { moles })\end{array}$ & & & & $\%$ & & & \\
\hline A. & $\begin{array}{l}7 \\
4\end{array}$ & $\begin{array}{l}\text { Normal } \\
\text { Irrigated }\end{array}$ & $\begin{array}{l}22.3 \pm 4.4^{\dagger} \\
46.9 \pm 8.6\end{array}$ & $\begin{array}{r}92.3 \pm 3.4 \\
2.9 \pm 1.5\end{array}$ & $\begin{array}{r}3.9 \pm 1.8 \\
93.2 \pm 5.8\end{array}$ & $\begin{array}{l}2.3 \pm 2.4 \\
3.7 \pm 4.1\end{array}$ & $\begin{array}{l}1.4 \pm 0.4 \\
0.1 \pm 0.08\end{array}$ \\
\hline $\begin{array}{l}\text { Tripalmitin } \\
\left(10 \times 10^{6} \mathrm{dpm},\right. \\
5 \mu \text { moles })\end{array}$ & & & & & & & \\
\hline A. & $\begin{array}{l}6 \\
4\end{array}$ & $\begin{array}{l}\text { Normal } \\
\text { Irrigated }\end{array}$ & $\begin{array}{l}49.0 \pm 3.4 \\
59.6 \pm 9.3\end{array}$ & $\begin{array}{r}29.0 \pm 7.0 \\
1.0 \pm 0.3\end{array}$ & $\begin{array}{l}62.5 \pm 8.3 \\
98.0 \pm 2.0\end{array}$ & $\begin{array}{l}1.5 \pm 0.2 \\
0.5 \pm 1.5\end{array}$ & $\begin{array}{l}7.0 \pm 1.2 \\
0.5 \pm 0.1\end{array}$ \\
\hline
\end{tabular}

* Lipid substrate was suspended in $1.0 \mathrm{ml} 10 \%$ crystalline bovine albumin.

$\dagger$ Abbreviations: TG, triglyceride; DG, diglyceride; MG, monoglyceride.

+ Mean \pm 1 SD.

junction above the entrance of the biliary and pancreatic ducts. In irrigated loops, which were employed to reduce intraluminal concentrations of pancreatic enzymes and bile salts, the isolated loops were flushed with 50 $\mathrm{ml}$ of $0.85 \% \mathrm{NaCl}$. The proximal ligature was then placed below the entrance of the biliary and pancreatic ducts. The various radioactive lipids, suspended in $10 \%$ albumin, were then injected into the loop in a volume of about $1 \mathrm{ml}$.

After 15 minutes the isolated loops were excised and the intestinal contents washed out with $50 \mathrm{ml}$ of $0.85 \%$ $\mathrm{NaCl}$. The luminal contents were acidified with $1.0 \mathrm{ml}$ of $12 \mathrm{~N} \mathrm{HCl}$ and extracted with $100 \mathrm{ml}$ of hexane. The aqueous and lipid phases were separated and samples assayed for radioactivity. The intestinal mucosa was removed from the loops by scraping, weighed, and the lipids extracted by the method of Folch, Lees, and Sloane Stanley (4). In experiments with palmitic acid and tripalmitin as radioactive substances, the solvents containing. the extracted lipids were evaporated to dryness under a stream of nitrogen at room temperature and the residues redissolved in chloroform. In experiments with octanoic acid and trioctanoin as substrates, the chloroform-methanol $(2: 1)$ added during the experiment contained $42 \mu$ moles of carrier octanoic acid and $6 \mu$ moles of carrier trioctanoin, and the $\mathrm{pH}$ during the Folch extraction was adjusted to below 3. Because of the volatility of octanoic acid, the solvents containing the lipid extracts were evaporated slowly under a nitrogen stream at $0^{\circ} \mathrm{C}$. Recovery of octanoic acid $-{ }^{14} \mathrm{C}$ under these conditions was greater than $95 \%$ in control studies. The dried extracts were then resuspended in chloroform. Samples of the lipid extracts were assayed for radioactivity and analyzed by thin layer chromatography.

The question might be raised as to whether some of the ${ }^{14} \mathrm{C}$-labeled lipid injected into isolated loops was adsorbed to the intestinal mucosa thus resulting in a spuriously elevated mucosal uptake. To exclude this possibility, preliminary studies were carried out in which trioctanoin- carboxyl- ${ }^{14} \mathrm{C}$ and tripalmitin-carboxyl- ${ }^{14} \mathrm{C}$ were injected into intestinal loops, which were excised within 30 seconds. Under these conditions greater than $90 \%$ of the ${ }^{14} \mathrm{C}$-labeled lipid injected was recovered in the luminal contents. Although some adsorption of ${ }^{14} \mathrm{C}$-labeled lipids to intestinal mucosa undoubtedly did occur, we felt it to be insignificant.

Absorption of radioactive lipid substrates from isolated intestinal loops was also assessed by determining ${ }^{14} \mathrm{C}$ activity in portal venous and aortic blood, either $15 \mathrm{~min}$ utes or 60 minutes after the injection of the ${ }^{14} \mathrm{C}$-labeled lipids. Plasma samples were extracted by the method of Folch and associates (4) and the aqueous and lipid extracts assayed for radioactivity. The lipids were also fractionated by thin layer chromatography.

Experiments with acetoxycycloheximide ( $\mathrm{ACH})$. Studies were carried out to determine the effect of inhibiting protein synthesis on the absorption of carboxyl${ }^{14} \mathrm{C}$-trioctanoin and carboxyl- ${ }^{14} \mathrm{C}$-tripalmitin. $\mathrm{ACH}$, an antibiotic that has been found to inhibit protein synthesis in mammalian cells (5), was injected intraperitoneally in a dosage of $0.25 \mathrm{mg}$ per $\mathrm{kg} 4$ hours before the preparation of the intestinal loops.

Studies on the hydrolysis of ${ }^{14} \mathrm{C}$-labeled lipids in vitro. The previously described methods of Playoust and Isselbacher (6) were utilized in these studies. Crude pancreatic lipase ${ }^{3}$ was dissolved in $0.154 \mathrm{M} \mathrm{KCl}$ containing $0.01 \mathrm{M}$ sodium phosphate, $\mathrm{pH}$ 7.4. Intestinal juice was obtained from either normal or irrigated loops $15 \mathrm{~min}$ utes after $1.5 \mathrm{ml}$ of $0.85 \% \mathrm{NaCl}$ had been injected into the loops. The protein content of the intestinal juice and pancreatic lipase was determined by the method of Lowry, Rosebrough, Farr, and Randall (7). The incubations were carried out in stoppered tubes at $37^{\circ} \mathrm{C}$ for 10 minutes. The usual incubation mixture consisted of $1.0 \mathrm{ml}$ of ${ }^{14} \mathrm{C}$-labeled lipid-albumin suspension; $0.5 \mathrm{ml}$ of fivefold concentrated low calcium Krebs-Ringer phos-

\footnotetext{
${ }^{3}$ Sigma Chemical Co., St. Louis, Mo.
} 


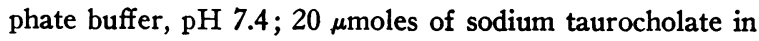
$0.1 \mathrm{ml}$ of $0.154 \mathrm{M} \mathrm{KCl}$; and $0.1 \mathrm{ml}$ of either intestinal juice or lipase solution. The final volume was $1.7 \mathrm{ml}$. The incubations were terminated by placing the test tubes in an alcohol-ice bath at $-15^{\circ} \mathrm{C}$ for 1 minute. Chilled chloroform-methanol $(2: 1)$ was then added, and the lipids were extracted by the method of Folch and co-workers (4). Samples of the lipid extracts were assayed for radioactivity and also fractionated by thin layer chromatography.

\section{Results}

Hydrolysis of trioctanoin and tripalmitin in vivo and in vitro. In Table I are shown data on the relative rates of hydrolysis of ${ }^{14} \mathrm{C}$-labeled lipids in isolated intestinal loops in 15 minutes. When trioctanoin was injected into normal loops, almost all of the lipid remaining in the luminal contents (92\%) was present as fatty acid, whereas with tripalmitin, only $29 \%$ of the residual ${ }^{14} \mathrm{C}$-labeled lipid had been hydrolyzed to fatty acid. After trioctanoin and tripalmitin were injected into loops that had been previously irrigated to reduce the concentration of bile salts and pancreatic lipase, there was marked impairment in the hydrolysis of both glycerides (Table I).
TABLE II

In vitro hydrolysis of ${ }^{14} \mathrm{C}$-labeled lipids by juice from intestinal loops*

\begin{tabular}{|c|c|c|c|}
\hline $\begin{array}{c}\text { Lipid-14C } \\
\text { substrate } \\
\text { (200 m m moles) }\end{array}$ & $\begin{array}{c}\text { No. } \\
\text { experi- } \\
\text { ments }\end{array}$ & $\begin{array}{c}\text { Source of } \\
\text { intestinal } \\
\text { juicet }\end{array}$ & $\begin{array}{c}\text { Fatty acid } \\
\text { liberated } \\
\text { (10 minutes) }\end{array}$ \\
\hline & & ' & $\underset{m \mu \text { protein }}{m, 0.3}$ \\
\hline \multirow{2}{*}{ Trioctanoin } & 7 & Normal loop & $146.7 \pm 16.3 \ddagger$ \\
\hline & 6 & Irrigated loop & $16.6 \pm 4.7$ \\
\hline \multirow[t]{2}{*}{ Tripalmitin } & 5 & Normal loop & $28.7 \pm 6.0$ \\
\hline & 5 & Irrigated loop & $3.0 \pm 0.8$ \\
\hline
\end{tabular}

* Each incubation mixture contained $1.0 \mathrm{ml}{ }^{14} \mathrm{C}$-labeled lipid albuminsuspension with $200 \mathrm{~m} \mu$ moles of triglyceride; $0.5 \mathrm{ml}$ of fivefold concentrated low calcium Krebs-Ringer phosphate buffer, pH 7.4; $20 \mu$ moles of sodium taurocholate in $0.1 \mathrm{ml}$ of $0.154 \mathrm{M} \mathrm{KCl}$ with $0.01 \mathrm{M}$ phosphate, pH 7.4 ; and $0.1 \mathrm{ml}$ intestinal juice. The final volume was $1.7 \mathrm{ml}$. The incubations were carried out for 10 minutes at $37^{\circ} \mathrm{C}$ and were terminated by placement in an alcohol-ice bath $\left(-15^{\circ} \mathrm{C}\right)$

$\dagger$ Juice obtained 15 minutes after injection of $1.5 \mathrm{ml}$ saline into loops. $\ddagger$ Mean \pm 1 SD.

To confirm that trioctanoin is hydrolyzed more rapidly than tripalmitin, we undertook in vitro studies utilizing juice from either normal or irrigated intestinal loops (Table II). After incubating $200 \mathrm{~m} \mu$ moles of trioctanoin with juice from a normal loop, $147 \mathrm{~m} \mu$ moles of fatty acid was liberated in 10 minutes. Under these conditions only $29 \mathrm{~m} \mu$ moles of fatty acid was liberated from

TABLE III

In vitro hydrolysis of trioctanoin-carboxyl-14 $C$ and tripalmitin-carboxyl-14 $C$ by intestinal juice and pancreatic lipase*

\begin{tabular}{|c|c|c|c|c|c|}
\hline \multirow{2}{*}{$\begin{array}{c}\text { Lipid-14C } \\
\text { substrate } \\
\text { (200 m } \mu \text { moles) }\end{array}$} & \multicolumn{2}{|c|}{ Source of enzyme } & \multirow[b]{2}{*}{ Experimental condition } & \multirow{2}{*}{$\begin{array}{c}\text { Fatty acid } \\
\text { liberated } \\
\text { in 10 } \\
\text { minutes }\end{array}$} & \multirow[b]{2}{*}{ Inhibition } \\
\hline & $\begin{array}{c}\text { Intestinal } \\
\text { juicet }\end{array}$ & $\begin{array}{l}\text { Pancreatic } \\
\text { lipase }\end{array}$ & & & \\
\hline \multirow{9}{*}{ Trioctanoin } & & & \multirow{3}{*}{ Control } & $\begin{array}{c}\text { mumoles } / \\
0.3 \mathrm{mg} \text { protein }\end{array}$ & \\
\hline & + & & & 169.4 & \\
\hline & & + & & 166.5 & \\
\hline & + & & \multirow{2}{*}{ Heat, $50^{\circ} \mathrm{C}(10 \mathrm{~min})$} & 122.9 & 27.4 \\
\hline & & + & & 90.7 & 45.6 \\
\hline & + & & \multirow{2}{*}{$0.02 \mathrm{M} \mathrm{KF}$} & 115.9 & 31.6 \\
\hline & & + & & 109.7 & 34.1 \\
\hline & + & & \multirow{2}{*}{$0.001 \mathrm{M} \mathrm{PCMB} \ddagger$} & 155.8 & 8.0 \\
\hline & & + & & 153.8 & 7.7 \\
\hline \multirow[t]{2}{*}{ Tripalmitin } & + & & \multirow{2}{*}{ Control } & 28.7 & \\
\hline & & + & & 166.3 & \\
\hline
\end{tabular}

. * The incubation mixtures were identical to those described in Table II and contained either $0.1 \mathrm{ml}$ of lipase solution $(0.3 \mathrm{mg}$ protein) or $0.1 \mathrm{ml}$ of intestinal juice $(0.3$ to $0.6 \mathrm{mg}$ protein). The incubations were carried out for $10 \mathrm{minutes}$ at $37^{\circ} \mathrm{C}$ and terminated by placement in an alcohol-ice bath at $-15^{\circ} \mathrm{C}$. The data shown represent the mean values of two sets of experiments carried out in duplicate.

t Obtained 15 minutes after injection of $1.5 \mathrm{ml}$ saline into normal loops.

$\ddagger$ PCMB $=p$-chloromercuribenzoate. 
TABLE IV

Absorption of ${ }^{14} \mathrm{C}$-labeled lipids from isolated intestinal loops

\begin{tabular}{|c|c|c|c|c|c|c|}
\hline \multirow{3}{*}{$\begin{array}{l}\text { Lipid-14C substrate* } \\
\text { Octanoic acid } \\
\left(9.9 \times 10^{6} \mathrm{dpm}\right. \\
10 \mu \text { moles })\end{array}$} & \multirow{3}{*}{$\begin{array}{c}\begin{array}{c}\text { No. } \\
\text { experi- } \\
\text { ments }\end{array} \\
4\end{array}$} & \multirow{3}{*}{$\begin{array}{c}\begin{array}{c}\text { Type } \\
\text { loop }\end{array} \\
\text { Irrigated }\end{array}$} & \multicolumn{4}{|c|}{$\%$ of administered radioactivity } \\
\hline & & & \multirow{2}{*}{$\begin{array}{c}\begin{array}{c}\text { Recovered } \\
\text { in loop } \\
\text { contents }\end{array} \\
14.0 \pm 5.8 \dagger \\
\end{array}$} & \multirow{2}{*}{$\begin{array}{c}\begin{array}{c}\mathrm{A} \\
\text { Mucosal } \\
\text { uptake }\end{array} \\
86.0 \pm 7.0\end{array}$} & \multirow{2}{*}{$\begin{array}{c}\begin{array}{c}\text { B } \\
\text { Remaining } \\
\text { in mucosa }\end{array} \\
4.2 \pm 1.5\end{array}$} & $\begin{array}{c}\mathrm{A}-\mathrm{B} \\
\text { Mucosal } \\
\text { transfer }\end{array}$ \\
\hline & & & & & & $81.8 \pm 7.5$ \\
\hline $\begin{array}{l}\text { Palmitic acid } \\
\quad\left(5.4 \times 10^{6} \mathrm{dpm}\right. \\
10 \mu \mathrm{moles})\end{array}$ & 4 & Irrigated & $19.1 \pm 3.3$ & $80.9 \pm 2.3$ & $46.1 \pm 9: 7$ & $34.8 \pm 11.8$ \\
\hline \multicolumn{7}{|l|}{$\begin{array}{l}\text { Trioctanoin } \\
\left(10 \times 10^{6} \mathrm{dpm},\right. \\
5 \mu \text { moles })\end{array}$} \\
\hline $\begin{array}{l}\text { A. } \\
\text { B. }\end{array}$ & $\begin{array}{l}7 \\
8\end{array}$ & $\begin{array}{l}\text { Normal } \\
\text { Irrigated }\end{array}$ & $\begin{array}{l}22.3 \pm 4.4 \\
46.9 \pm 8.6\end{array}$ & $\begin{array}{l}77.7 \pm 4.4 \\
53.1 \pm 9.0\end{array}$ & $\begin{array}{r}6.4 \pm 1.5 \\
16.5 \pm 6.1\end{array}$ & $\begin{array}{l}71.3 \pm 3.8 \\
36.6 \pm 9.6\end{array}$ \\
\hline \multicolumn{7}{|l|}{$\begin{array}{l}\text { Tripalmitin } \\
\qquad\left(10 \times 10^{6} \mathrm{dpm},\right. \\
5 \mu \text { moles })\end{array}$} \\
\hline $\begin{array}{l}\text { A. } \\
\text { B. }\end{array}$ & $\begin{array}{l}7 \\
6\end{array}$ & $\begin{array}{l}\text { Normal } \\
\text { Irrigated }\end{array}$ & $\begin{array}{l}49.0 \pm 3.4 \\
59.6 \pm 9.3\end{array}$ & $\begin{array}{l}51.0 \pm 3.1 \\
40.4 \pm 9.3\end{array}$ & $\begin{array}{l}20.2 \pm 3.0 \\
17.3 \pm 3.2\end{array}$ & $\begin{array}{l}30.8 \pm 3.3 \\
23.1 \pm 9.4\end{array}$ \\
\hline
\end{tabular}

* Lipid substrate was suspended in $1.0 \mathrm{ml} 10 \%$ crystalline bovine albumin.

$\dagger$ Mean \pm standard deviation.

tripalmitin, a fivefold difference. When incubations were carried out with juice from irrigated loops, there was, as expected, impaired hydrolysis of both trioctanoin and tripalmitin. Even under these conditions, however, there was still five times as much fatty acid liberated from trioctanoin as from tripalmitin (viz., 16.6 vs. $3.0 \mathrm{~m} \mu$ moles).

It was considered possible that the more rapid hydrolysis of trioctanoin as compared to tripalmitin might in part be due to a mucosal lipase (6). Such a lipase in the luminal contents could appear as a result of intestinal cells being extruded into the lumen. To evaluate this possibility, we carried out studies to determine whether the lipolytic activity in intestinal juice had the characteristics of pancreatic or mucosal lipase. In view of previous observations (6) that demonstrated the mucosal lipase to be inhibited by potassium fluoride, $p$-chloromercuribenzoate, and heat, studies were carried out utilizing these metabolic inhibitors. Under these conditions (Table III) there was a comparable decrease in the lipolytic activity of both pancreatic lipase and intestinal juice, indicating that the lipolytic activity of intestinal juice was due to the presence of pancreatic lipase.
Absorption of ${ }^{14} \mathrm{C}$-labeled lipids from intestinal loops. In Table IV are shown data on the relative rates of absorption of trioctanoin and tripalmitin. These were determined by measuring the mucosal uptake and mucosal transfer of ${ }^{14} \mathrm{C}$-labeled lipids. Mucosal uptake (A) was determined by subtracting the amount of ${ }^{14} \mathrm{C}$-labeled lipid recovered in the loop contents from the amount injected. The amount of ${ }^{14} \mathrm{C}$-labeled lipid remaining in the mucosa (B) was determined directly. Mucosal transfer represents the difference between mucosal uptake (A) and the amount remaining in the mucosa (B). In essence therefore, mucosal transfer $(A-B)$ reflects net absorption.

When albumin suspensions of octanoic or pal. mitic acid were injected into irrigated loops, the mucosal uptakes were quite similar (86 vs. $81 \%$ ). However, with octanoic acid less ${ }^{14} \mathrm{C}$ was recovered in the mucosa compared to palmitic acid (4 vs. $46 \%$ ). Furthermore, in 15 minutes the mucosal transfer of octanoic acid was much greater than that of palmitic acid ( $82 \mathrm{vs.} 35 \%$ ).

When the triglycerides rather than the fatty acids were injected into normal loops, there was a greater mucosal uptake of trioctanoin than of 
tripalmitin ( 78 vs. $51 \%, \mathrm{p}=<0.001$ ) and also a greater mucosal transfer of trioctanoin (71 vs. $31 \%, \mathrm{p}=<0.001)$. With irrigated loops, in which there was impaired intraluminal lipolysis, there was still a greater uptake of trioctanoin than of tripalmitin ( 53 vs. $40 \%, \mathrm{p}=<0.05$ ) as well as a greater transfer ( 37 vs. $23 \%, p=<0.05$ ). Thus in both normal and irrigated loops the net absorption of trioctanoin was greater than that of tripalmitin. This is shown diagrammatically in Figure 1.

The lipids present in intestinal mucosa and portal and aortic blood were analyzed by thin layer chromatography (Tables V and VI). When octanoic acid- ${ }^{14} \mathrm{C}$ was injected into irrigated loops, $88 \%$ of the labeled lipid in the mucosa was present as fatty acid, whereas after palmitic acid was given, $81 \%$ was present as triglyceride. The latter finding is consistent with the essential role of mucosal re-esterification in the transport of long chain fatty acids.

When trioctanoin was injected into normal loops, $67 \%$ of the ${ }^{14} \mathrm{C}$-labeled lipid recovered in the mucosa was present as fatty acid; this is reflected by $84 \%$ of the labeled lipid in portal blood also being present as fatty acid. To determine whether impaired intraluminal lipolysis would alter

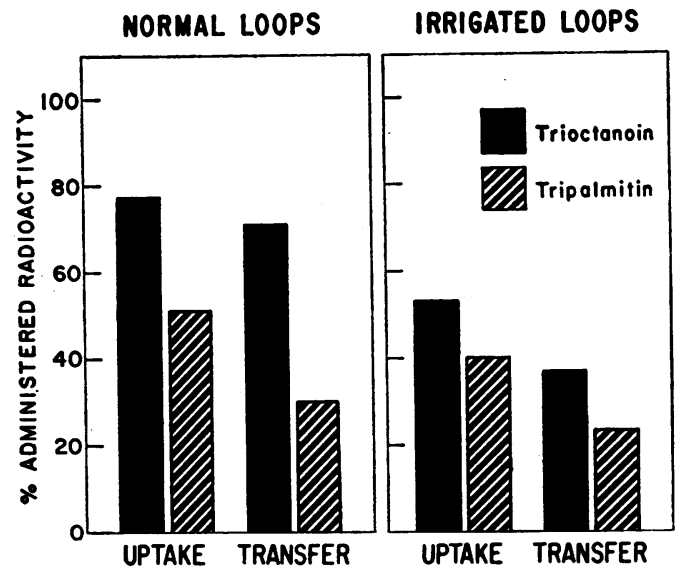

Fig. 1. THE MUCOSAL UPTAKe AND TRANSFER OF ${ }^{14} \mathrm{C}$ LABELED LIPIDS FROM NORMAL AND IRRIGATED INTESTINAL LOOPS.

this lipid pattern, we carried out similar studies with trioctanoin in irrigated loops. Under these conditions, the ${ }^{14} \mathrm{C}$-labeled lipid in the mucosa was present predominantly as neutral lipid, and $74 \%$ of the labeled lipid in portal blood was also in the neutral lipid fraction.

After tripalmitin had been injected into normal and irrigated loops, the ${ }^{14} \mathrm{C}$ recovered from the mucosa was, as expected, predominantly in the form of neutral lipid. Under the conditions of

TABLE V

Thin layer chromatographic analysis of mucosal lipids after the administration of ${ }^{14}$ C-labeled lipids to isolated intestinal loops*

\begin{tabular}{|c|c|c|c|c|c|c|c|c|}
\hline \multirow[b]{3}{*}{ Lipid-14C } & \multirow{3}{*}{$\begin{array}{l}\text { No. } \\
\text { experi- } \\
\text { ments }\end{array}$} & \multirow{3}{*}{$\begin{array}{l}\text { Type } \\
\text { loop }\end{array}$} & \multirow{3}{*}{$\begin{array}{l}\% \text { of dose } \\
\text { recovered } \\
\text { in mucosa }\end{array}$} & \multicolumn{5}{|c|}{$\%$ distribution of radioactivity in } \\
\hline & & & & \multicolumn{4}{|c|}{ Glyceridest } & \multirow{2}{*}{$\begin{array}{l}\text { Fatty } \\
\text { acids }\end{array}$} \\
\hline & & & & MG and PL & DG & TG & Total & \\
\hline $\begin{array}{l}\text { Octanoic acid } \\
\left(9.9 \times 10^{6} \mathrm{dpm}\right. \\
10 \mu \text { moles })\end{array}$ & 3 & Irrigated & $4.2 \pm 1.5$ & $4.8 \pm 1.7$ & $5.8 \pm 1.2$ & $1.2 \pm 0.3$ & $11.9 \pm 2.3$ & $88.1 \pm 2.3$ \\
\hline $\begin{array}{l}\text { Palmitic acid } \\
\qquad\left(5.4 \times 10^{6} \mathrm{dpm}\right. \\
10 \mu \text { moles })\end{array}$ & 3 & Irrigated & $46.9 \pm 8.6$ & $6.1 \pm 0.9$ & $3.4 \pm 0.2$ & $80.8 \pm 2.2$ & $90.5 \pm 2.1$ & $9.5 \pm 2.1$ \\
\hline $\begin{array}{l}\text { Trioctanoin } \\
\left(10 \times 10^{6} \mathrm{dpm}\right. \\
5 \mu \text { moles })\end{array}$ & 4 & Irrigated & $\begin{array}{r}6.4 \pm 1.5 \\
16.5 \pm 6.1\end{array}$ & $\begin{array}{l}2.9 \pm 0.5 \\
0.2 \pm 0.1\end{array}$ & $\begin{array}{l}2.8 \pm 0.7 \\
0.7 \pm 0.2\end{array}$ & $\begin{array}{l}27.4 \pm 9.3 \\
93.1 \pm 0.9\end{array}$ & $\begin{array}{l}33.1 \pm 8.6 \\
94.1 \pm 0.7\end{array}$ & $\begin{array}{r}66.9 \pm 8.7 \\
5.9 \pm 0.9\end{array}$ \\
\hline $\begin{array}{l}\text { Tripalmitin } \\
\qquad\left(10 \times 10^{6} \mathrm{dpm}\right. \\
5 \mu \text { moles })\end{array}$ & 4 & Irrigated & $\begin{array}{l}20.2 \pm 3.0 \\
17.3 \pm 3.2\end{array}$ & $\begin{array}{l}6.5 \pm 1.7 \\
2.9 \pm 0.5\end{array}$ & $\begin{array}{l}3.4 \pm 0.4 \\
8.3 \pm 2.5\end{array}$ & $\begin{array}{l}73.3 \pm 6.8 \\
82.3 \pm 1.4\end{array}$ & $\begin{array}{l}83.2 \pm 5.5 \\
93.2 \pm 5.2\end{array}$ & $\begin{aligned} 16.8 & \pm 5.1 \\
6.8 & \pm 3.1\end{aligned}$ \\
\hline
\end{tabular}

* Mucosa obtained 15 minutes after administration of ${ }^{14}$ C-labeled lipids, extracted with chloroform-methanol (2:1), and applied to silicic acid plates. For details of thin layer chromatography see Methods. All chromatographic determinations were carried out in duplicate.

† Abbreviations: TG, triglyceride; DG, diglyceride; MG, monoglyceride; PL, phospholipid. 
TABLE VI

Thin layer chromatographic analysis of ${ }^{14} \mathrm{C}$-labeled lipids in intestinal mucosa, portal vein, and aortic blood after administration of the lipids to intestinal loops*

\begin{tabular}{|c|c|c|c|c|c|c|c|c|c|c|c|c|}
\hline \multirow[t]{3}{*}{ : } & \multirow[b]{3}{*}{$\begin{array}{c}\text { Lipid-14C } \\
(5 \mu \text { moles, } \\
\left.10 \times 10^{6} \mathrm{dpm}\right)\end{array}$} & \multirow[b]{3}{*}{$\begin{array}{l}\text { No. } \\
\text { experi- } \\
\text { ments }\end{array}$} & \multirow[b]{3}{*}{$\begin{array}{l}\text { Type } \\
\text { loop }\end{array}$} & \multicolumn{9}{|c|}{ Lipid-14C recovered (after 15 minutes) } \\
\hline & & & & \multicolumn{3}{|c|}{ Mucosa } & \multicolumn{3}{|c|}{ Portal blood } & \multicolumn{3}{|c|}{ Aorta } \\
\hline & & & & $\begin{array}{l}\mathrm{dpm} / \\
\left(\times 10^{-3}\right) / \\
\mathrm{g} \text { mucosa }\end{array}$ & $\begin{array}{l}\text { Li } \\
\text { Fatty } \\
\text { acid }\end{array}$ & $\mathrm{d}_{\text {tral }}^{\mathrm{Neu}-}$ & $\underset{\left(\times 10^{-z}\right)}{\mathrm{dpm} / \mathrm{ml}}$ & $\begin{array}{c}\text { L } \\
\text { Fatty } \\
\text { acid }\end{array}$ & $\overline{\substack{\text { Neu- } \\
\text { tral }}}$ & $\underset{\left(\times 10^{-3}\right)}{\mathrm{dpm} / \mathrm{ml}}$ & $\begin{array}{c}\text { L } \\
\text { Fatty } \\
\text { acid }\end{array}$ & Neu- \\
\hline & & & & & \multicolumn{2}{|c|}{$\%$} & \multicolumn{3}{|c|}{$\%$} & & \multicolumn{2}{|c|}{$\%$} \\
\hline & \multirow{2}{*}{ Trioctanoin } & 4 & Normal & 640 & 67 & 33 & 40.3 & 83 & 16 & 25.0 & 23 & 77 \\
\hline & & 4 & Irrigated & 1,650 & 6 & 94 & 3.8 & 26 & 74 & 5.4 & 27 & 73 \\
\hline & \multirow[t]{2}{*}{ Tripalmitin } & 6 & Normal & 2,020 & 17 & 83 & 1.8 & & & 3.3 & 24 & 76 \\
\hline & & 6 & Irrigated & 1,750 & 7 & 93 & 0.4 & & & 0.8 & & \\
\hline
\end{tabular}

* For details of thin layer chromatography see Methods. All chromatographic determinations were carried out in duplicate.

these experiments there was not enough radioactivity in the portal blood samples to permit meaningful analysis by thin layer chromatography.

Effect of inhibition of protein synthesis on absorption of ${ }^{14} \mathrm{C}$-labeled lipids. Since lipoproteins have been shown to be essential for the transport of long chain triglycerides from intestinal mucosa $(8,9)$, experiments were carried out with $\mathrm{ACH}$ to determine the effect of impaired protein synthesis on the mucosal uptake and transfer of ${ }^{14} \mathrm{C}$ labeled lipids from intestinal loops (Table VII). In studies. with trioctanoin, prior $\mathrm{ACH}$ treatment resulted in a slight decrease in mucosal uptake compared to controls (65 vs. $78 \%$ ) as well as mucosal transfer ( 52 vs. $71 \%$ ). Consistent with this latter finding was the twofold increase in ${ }^{14} \mathrm{C}$ recovered from the mucosa compared to controls (13 vs. $6 \%$, Table VII).

After tripalmitin had been given to $\mathrm{ACH}$-treated rats, there was a moderate decrease in mucosal uptake compared to controls ( 51 vs. $36 \%$ ). However, the striking finding was the marked decrease in the mucosal transfer of tripalmitin, namely from $31 \%$ to $9 \%(\mathrm{p}=<0.001)$.

To document further the impaired transport of tripalmitin after $\mathrm{ACH}$ treatment, we carried out studies in which samples of portal and aortic blood were obtained 60 minutes after injection of tripalmitin into intestinal loops. The lipids were fractionated by thin layer chromatography and samples assayed for radioactivity. In $\mathrm{ACH}$ rats receiving tripalmitin (Table VIII) there was a greater than $90 \%$ decrease in the amount of ${ }^{14} \mathrm{C}$-labeled lipid recovered in aortic and portal blood compared to controls. In similar studies with trioctanoin there was only a minimal decrease in ${ }^{14} \mathrm{C}$-labeled lipid recovered in $\mathrm{ACH}$-treated rats.

The ratio of ${ }^{14} \mathrm{C}$ recovered in the portal vein and the aorta reflects the different routes of transport of trioctanoin and tripalmitin. The ratio of

TABLE VII

Absorption of ${ }^{14}$ C-labeled lipids from normal intestinal loops in acetoxycycloheximide-treated rats*

\begin{tabular}{|c|c|c|c|c|c|c|}
\hline \multirow[b]{2}{*}{ Group } & \multirow[b]{2}{*}{$\begin{array}{l}\text { No. } \\
\text { experi- } \\
\text { ments }\end{array}$} & \multirow{2}{*}{$\begin{array}{c}\text { Lipid-14C } \\
\text { substrate given } \dagger \\
(5 \mu \text { moles, } \\
\left.10 \times 10^{6} \mathrm{dpm}\right)\end{array}$} & \multicolumn{4}{|c|}{$\%$ of administered radioactivity } \\
\hline & & & $\begin{array}{l}\text { Recovered in } \\
\text { loop contents }\end{array}$ & $\underset{\substack{\text { Mucosal } \\
\text { uptake }}}{\mathbf{A}}$ & $\begin{array}{c}\text { B } \\
\text { Remaining } \\
\text { in mucosa }\end{array}$ & $\begin{array}{c}\text { A-B } \\
\text { Mucosal } \\
\text { transfer }\end{array}$ \\
\hline Control & 7 & Trioctanoin & $22.3 \pm 4.4 \ddagger$ & $77.7 \pm 4.0$ & $6.4 \pm 1.5$ & $71.3 \pm 3.8$ \\
\hline $\begin{array}{l}\text { Acetoxycyclo- } \\
\text { heximide }\end{array}$ & 6 & Trioctanoin & $35.1 \pm 6.9$ & $64.9 \pm 7.0$ & $13.0 \pm 0.9$ & $51.9 \pm 7.0$ \\
\hline Control & 7 & Tripalmitin & $49.0 \pm 3.4$ & $51.0 \pm 3.1$ & $20.2 \pm 3.0$ & $30.8 \pm 3.3$ \\
\hline $\begin{array}{l}\text { Acetoxycyclo- } \\
\text { heximide }\end{array}$ & 5 & Tripalmitin & $64.5 \pm 5.8$ & $35.5 \pm 7.0$ & $26.9 \pm 7.0$ & $8.6 \pm 3.6$ \\
\hline
\end{tabular}

* Rats received acetoxycycloheximide in a dosage of $0.25 \mathrm{mg}$ per $\mathrm{kg} 4$ hours before construction of a normal loop. $\dagger$ Lipid substrate was suspended in $1.0 \mathrm{ml}$ of $10 \%$ crystalline bovine albumin.

$\ddagger$ Mean \pm 1 SD. 
TABLE VIII

Absorption of ${ }^{14}$ C-labeled lipids from normal intestinal loops in acetoxycycloheximide-treated rats*

\begin{tabular}{|c|c|c|c|c|c|c|}
\hline \multirow[b]{2}{*}{ Group } & \multirow{2}{*}{$\begin{array}{c}\text { No. } \\
\text { experi- } \\
\text { ments }\end{array}$} & \multirow{2}{*}{$\begin{array}{c}\text { Lipid-14C } \\
\text { substrate given } \\
(5 \mu \text { moles, } \\
\left.20 \times 10^{6} \mathrm{dpm}\right)\end{array}$} & \multicolumn{2}{|c|}{${ }^{14} \mathrm{C}$ recovered (after 60 minutes) } & \multirow{2}{*}{$\begin{array}{l}\text { Portal } \\
\text { vein/ } \\
\text { aorta }\end{array}$} & \\
\hline & & & Portal vein & Aorta & & \\
\hline & & \multicolumn{5}{|c|}{$d p m / m l \times\left(10^{-z}\right)$ plasma } \\
\hline Control & 4 & Trioctanoin & $60.4 \pm 21.1 \dagger$ & $46.1 \pm 7.5$ & 1.31 & \\
\hline $\begin{array}{l}\text { Acetoxycyclo- } \\
\text { heximide }\end{array}$ & 5 & Trioctanoin & $55.9 \pm 14.7$ & $41.8 \pm 13.3$ & 1.34 & \\
\hline Control & 5 & Tripalmitin & $32.1 \pm 14.2$ & $59.5 \pm 19.0$ & 0.54 & r \\
\hline $\begin{array}{l}\text { Acetoxycyclo- } \\
\text { heximide }\end{array}$ & 4 & Tripalmitin & $1.9 \pm 1.7$ & $4.4 \pm 4.2$ & 0.43 & \\
\hline
\end{tabular}

* The conditions of the experiment were similar to those described in Table VII.

$\dagger$ Mean \pm 1 SD.

1.3 observed after trioctanoin injection is consistent with the fact that the portal vein is the primary route of absorption of medium chain fatty acids, whereas the ratio of 0.54 observed after tripalmitin administration reflects the greater lymphatic transport of long chain fatty acids ( $\mathrm{Ta}$ - ble VIII). In spite of the decrease in the recovery of ${ }^{14} \mathrm{C}$ after $\mathrm{ACH}$ treatment there was no difference in these ratios.

Sections of jejunum were taken for histological examination 4 hours after treatment with $\mathrm{ACH}$. Although there was no evidence of mucosal ne-

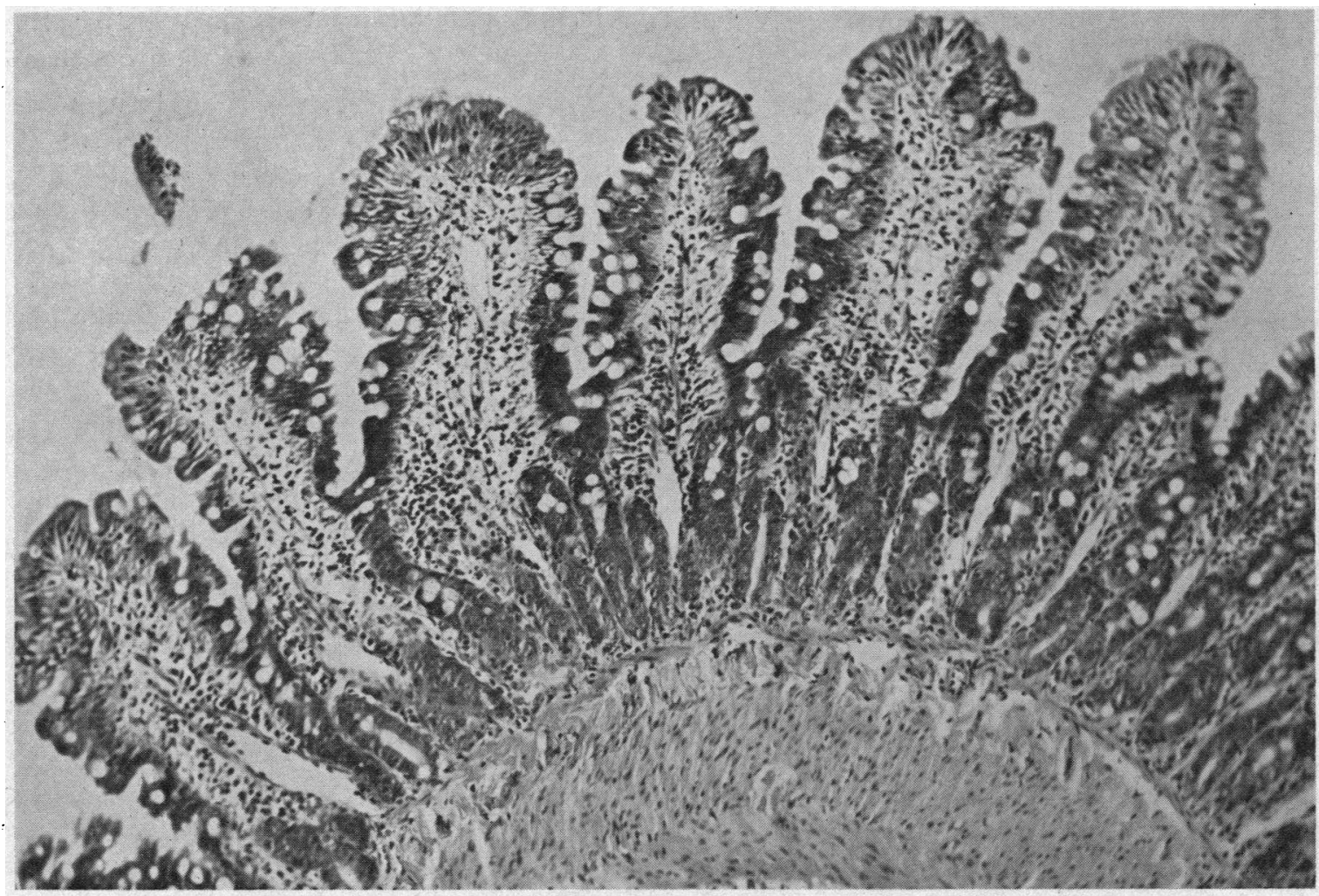

Fig. 2. Photomicrograph of Rat Jejunum 4 hours after acetoxycycloheximide, 0.25 mg Per Kg. The villi are slightly blunted due to edema of the villous core. There are focal areas in which the surface epithelium seems disorganized; however, this appearance is seemingly due to the extreme prominence of the goblet cells rather than actual epithelial cell necrosis. 
TABLE IX

Thin layer chromatographic analysis of mucosal lipids after administration of ${ }^{14} \mathrm{C}$-labeled lipids to acetoxycycloheximide-treated rats

\begin{tabular}{|c|c|c|c|c|c|c|c|c|c|}
\hline \multirow[b]{3}{*}{ Group } & \multirow{3}{*}{$\begin{array}{c}\text { Lipid-14C } \\
(5 \mu \text { moles, } \\
\left.10 \times 10^{6} \mathrm{dpm}\right)\end{array}$} & \multirow{3}{*}{$\begin{array}{l}\text { No. } \\
\text { experi- } \\
\text { ments }\end{array}$} & \multirow{3}{*}{$\begin{array}{l}\text { Type } \\
\text { loop }\end{array}$} & \multirow{3}{*}{$\begin{array}{l}\% \text { of dose } \\
\text { recovered } \\
\text { in mucosa }\end{array}$} & \multicolumn{5}{|c|}{$\%$ distribution of radioactivity in } \\
\hline & & & & & \multicolumn{4}{|c|}{ Glycerides } & \multirow{2}{*}{$\begin{array}{l}\text { Fatty } \\
\text { acid }\end{array}$} \\
\hline & & & & & MG and PL & DG & TG & Total & \\
\hline Control & Trioctanoin & 6 & Normal & $6.4 \pm 1.5^{*}$ & $2.9 \pm 0.5$ & $2.8 \pm 0.7$ & $27.4 \pm 9.3$ & $33.1 \pm 8.6$ & $66.9 \pm 8.6$ \\
\hline $\begin{array}{l}\text { Acetoxy- } \\
\text { cyclohex- } \\
\text { imide }\end{array}$ & & 7 & & $13.0 \pm 0.9$ & $6.6 \pm 1.6$ & $6.6 \pm 1.6$ & $22.2 \pm 6.4$ & $34.2 \pm 4.8$ & $65.8 \pm 4.6$ \\
\hline Control & Tripalmitin & 7 & Normal & $20.2 \pm 3.0$ & $6.5 \pm 1.7$ & $3.4 \pm 0.4$ & $73.3 \pm 6.8$ & $83.2 \pm 5.5$ & $16.8 \pm 5.1$ \\
\hline $\begin{array}{l}\text { Acetoxy- } \\
\text { cyclohex- } \\
\text { imide }\end{array}$ & & 5 & & $26.9 \pm 3.3$ & $6.7 \pm 0.2$ & $12.4 \pm 0.2$ & $56.7 \pm 2.1$ & $75.9 \pm 1.9$ & $24.1 \pm 1.9$ \\
\hline
\end{tabular}

$*$ Mean \pm 1 SD.

crosis, definite alterations in the villi and surface epithelium were noted (Figure 2 ). The villi appeared blunted due to edema of the villous core, and the surface epithelium showed focal areas of disorganization. This appearance was due in part to the extreme prominence of the mucous glands that were vacuolated, suggesting discharge of their contents. In previous experiments with puromycin and ethionine, no evidence of mucosal damage was noted by either light or electron microscopy (9-11).

Since $\mathrm{ACH}$ administration did result in apparent mucosal damage, studies were carried out to determine whether $\mathrm{ACH}$ treatment interfered with the mucosal processes of hydrolysis of trioctanoin and re-esterification of palmitic acid (Table IX). When trioctanoin was injected into $\mathrm{ACH}$-treated animals, $66 \%$ of the ${ }^{14} \mathrm{C}$-labeled lipid in the mucosa was present as fatty acid, a value nearly identical to the control value of $67 \%$. When tripalmitin was given to $\mathrm{ACH}$-treated rats, $76 \%$ of the labeled lipid in the mucosa was present as neutral lipid as compared with $83 \%$ in controls. Thus $\mathrm{ACH}$ treatment did not interfere with the mucosal hydrolysis of trioctanoin or the re-esterification of palmitic acid to neutral lipids. These results are comparable to those observed with puromycin (9).

\section{Discussion}

Although it seems reasonably well established on the basis of in vitro studies $(12,13)$ that triglycerides containing medium chain fatty acids are hydrolyzed more rapidly than long chain triglycerides, little quantitative data are available regard- ing rates of hydrolysis of triglycerides in vivo. The data obtained in the present investigation, based on in vivo and in vitro observations, indicate that trioctanoin, a medium chain triglyceride, is hydrolyzed by intestinal juice and pancreatic lipase more rapidly than tripalmitin, a long chain triglyceride. Furthermore, when intestinal loops are irrigated to impair intraluminal lipolysis, there is still a greater hydrolysis of trioctanoin than of tripalmitin. These data are consistent with previous in vitro observations of Desnuelle and his associates $(12,13)$, who demonstrated that short and medium chain triglycerides are hydrolyzed more rapidly than long chain triglycerides. These authors have suggested that medium chain triglycerides may be split rapidly by pancreatic lipase because of an especially high rate of isomerization of medium chain 2-monoglycerides, and they have recently presented evidence that medium chain 2 -monoglycerides do in fact isomerize very rapidly compared to long chain 2-monoglycerides (14).

In view of earlier demonstrations of a mucosal lipase system capable of hydrolyzing trioctanoin, we wished to determine whether the more rapid hydrolysis of trioctanoin is due to the presence of this lipase system in intestinal juice. On the basis of the known properties of pancreatic and mucosal lipase (6) and the data in Table III, it is apparent that the lipolytic activity of the intestinal juice used in these studies had characteristics of pancreatic lipase rather than the mucosal lipase system.

In irrigated loops there was still a significant absorption of tripalmitin with $40 \%$ of the injected dose being taken up by the mucosa and $23 \%$ be- 
ing transferred. At first glance it would appear that there should not have been this much absorption of a long chain triglyceride in the presence of impaired intraluminal lipolysis. However, a tracer dose of $5 \mu$ moles was used, and therefore there was mucosal uptake of only $2 \mu$ moles and mucosal transfer of $1 \mu$ mole of tripalmitin in 15 minutes. Moreover, these data are in agreement with an earlier study (6) in which there was mucosal uptake of $1 \mu$ mole of tripalmitin in an irrigated intestinal loop in 10 minutes. In addition, some absorption of long chain triglycerides has been shown to occur both in experimental animals (15) and man (16) after pancreatectomy. However, the mechanisms whereby significant amounts of long chain triglycerides may be absorbed in the apparent absence of pancreatic lipase remain unclear.

The data in Tables V and VI reflect the differences in the metabolism of medium chain fatty acids and triglycerides as compared to long chain fatty acids and triglycerides by the intestinal mucosa. After octanoic acid and trioctanoin had been injected into intestinal loops, the ${ }^{14} \mathrm{C}$-labeled lipid present in the mucosa was predominantly fatty acid, whereas after palmitic acid and tripalmitin had been given, the labeled lipid in the mucosa was mostly triglyceride. These data are in accord with current concepts of the intestinal absorption of lipids. Inside the intestinal mucosal cell, a medium chain triglyceride such as trioctanoin may be hydrolyzed by a mucosal lipolytic system (6), and medium chain monoglycerides are rapidly hydrolyzed by a glycerol monester hydrolase (monoglyceride lipase) $(17,18)$. In addition medium chain fatty acids are poorly activated to CoA thiol esters $(19,20)$. Thus after administration of either medium chain fatty acids or triglycerides, medium chain fatty acids accumulate in an unesterified form in the intestinal mucosa. In contrast, long chain fatty acids are readily activated to CoA thiol esters $(19,20)$ and incorporated into mucosal triglycerides, via the monoglyceride-shunt pathway (21-23) or the glycerol phosphate-phosphatidic acid pathway (24).

Therefore, it was not surprising that after the injection of trioctanoin into normal loops the ${ }^{14} \mathrm{C}$ labeled lipid recovered both in the mucosa and portal blood was present primarily as fatty acid. When trioctanoin was injected into an irrigated loop, however, the label recovered in the mucosa and portal blood was predominantly present in neutral lipid. These data suggest that when intraluminal lipolysis is impaired, some unhydrolyzed trioctanoin may enter the mucosal cell and be transported as such in the portal blood stream. For the reasons previously cited $(19,20)$, it is unlikely that the trioctanoin recovered was the result of hydrolysis to octanoic acid followed by re-esterification in the intestinal mucosa.

In the study of Playoust and Isselbacher (6) it was demonstrated that after trioctanoin had been injected into an irrigated loop, $88 \%$ of the labeled lipid in the mucosa was present as neutral lipid, but in the portal blood $85 \%$ of the ${ }^{14} \mathrm{C}$-labeled lipid was present as fatty acid. The latter observation is somewhat at variance with data presented in Table VI. In both studies, however, the ${ }^{14} \mathrm{C}-\mathrm{la}$ beled lipid recovered in the portal blood was only a small fraction of the administered dose, and thus the data can only be considered qualitative rather than quantitative. In addition, the portal blood was sampled at only one point in time, and the sampling time differed in the two studies. Obviously studies utilizing a continuous sampling technique are needed to define more clearly the quantitative aspects of trioctanoin transport in the portal blood stream. Nevertheless, it is evident from both studies that under certain conditions some unhydrolyzed trioctanoin may enter the mucosal cell and be transported as such.

As indicated previously, long chain fatty acids are esterified to triglycerides in the intestinal mucosa and then incorporated along with phospholipids, cholesterol, and a protein coating into a lipoprotein moiety known as chylomicrons. The proteins of the chylomicron are probably those synthesized within the intestinal mucosa (8). It has been demonstrated that after the administration of agents such as puromycin and ethionine, which inhibit protein and lipoprotein synthesis, the transport of long chain triglycerides is markedly impaired (9-11).

In the present investigation $\mathrm{ACH}$, an antibiotic derived from Streptomyces griseus and a potent inhibitor of protein synthesis in mammalian cells (5), was utilized to determine its effect on lipid transport. The data obtained (Tables VII and VIII) indicate that in $\mathrm{ACH}$-treated animals the mucosal transfer of tripalmitin was markedly im- 
paired, presumably because chylomicron formation was interfered with. In contrast, the mucosal transfer of trioctanoin was only minimally decreased by $\mathrm{ACH}$ treatment. In similar studies with ethionine (11), there was also markedly impaired mucosal transfer of tripalmitin but no impairment in the transfer of trioctanoin. In this connection, it is pertinent to emphasize that in previous experiments with puromycin and ethionine, no evidence of mucosal damage was noted by either light or electron microscopy (9-11). Possibly the minimal decrease in mucosal transfer of trioctanoin as well as the slight decrease in mucosal uptake of both trioctanoin and tripalmitin observed after $\mathrm{ACH}$ treatment was related to the fact that this drug was used in large doses that resulted in some morphologic alterations of the mucosa (Figure 2). Despite this apparent mucosal damage, there was not appreciable interference with the hydrolysis of trioctanoin and the re-esterification of palmitic acid to tripalmitin (Table IX).

Recent studies by Valdivieso and Schwabe (25, 26) have suggested that the absorption of trioctanoin is markedly impaired in rats with either a biliary fistula or surgically induced pancreatic insufficiency. These investigators reported that in such animals the absorptive defect could be corrected by administration of bile or pancreatic extracts (Cotazyme).

The present investigation indicates that bile salts and pancreatic lipase are important for optimal absorption of trioctanoin as well as tripalmitin. However, our data are at variance with those of Valdivieso and Schwabe as to the degree of impairment in the absorption of trioctanoin under conditions of bile salt or pancreatic enzyme deficiency. Our data suggest that significant amounts of trioctanoin may be absorbed with decreased intraluminal concentrations of pancreatic enzymes and bile salts.

It could be argued that since we used tracer amounts or lipid (5 or $10 \mu$ moles), the results might be different with physiological amounts of lipid substrate. However, in the study of Playoust and Isselbacher (6) $100 \mu$ moles of trioctanoin- ${ }^{14} \mathrm{C}$ was injected into irrigated intestinal loops in the rat, and $58 \%$ of the administered dose was taken up by the mucosa in 10 minutes.
There is also clinical evidence bearing on the absorption of medium chain triglycerides when pancreatic enzymes and bile salts are deficient. Hashim, Roholt, and Van Itallie (1) noted that in a patient with pancreatic insufficiency, administration of a medium chain triglyceride mixture resulted in a decrease in steatorrhea from 49 to $4.6 \mathrm{~g}$ per day. Similarly Iber, Hardoon, and Sprague (2) demonstrated a decrease in the steatorrhea from 40 to $13 \mathrm{~g}$ per day in a patient with pancreatic insufficiency given medium chain triglycerides. Iber and colleagues (2) also reported that in a patient with biliary tract obstruction given medium chain triglycerides, the steatorrhea decreased from 80 to $5 \mathrm{~g}$ per day. Recently Zurier, Hashim, and Van Itallie (27) reported that medium chain triglycerides significantly decreased cholestyramine-induced steatorrhea.

Thus, although bile salts and pancreatic enzymes are evidently necessary for the optimal absorption of medium chain triglycerides, clinical observations and the present studies indicate that significant amounts of these triglycerides may be absorbed when pancreatic enzymes and bile salts are deficient.

\section{Summary}

Although recent clinical observations have indicated that medium chain triglycerides may be useful in malabsorptive states, little quantitative data are available regarding the rates of absorption of medium chain triglycerides as compared to long chain triglycerides. In the present investigation studies were carried out in which the intestinal hydrolysis and absorption of trioctanoin, a medium chain triglyceride, were compared with those of tripalmitin, a long chain triglyceride, under a variety of different experimental conditions. These studies were performed utilizing isolated intestinal loops in the rat. In addition to normal loops, irrigated loops were used so that studies could be carried out under conditions of diminished intraluminal lipolysis.

The data obtained in our study indicate that 1) trioctanoin is both hydrolyzed and absorbed more rapidly than tripalmitin; 2) with markedly diminished intraluminal concentrations of pancreatic lipase and bile salts there is decreased absorption of both trioctanoin and tripalmitin, but 
under these conditions there is significantly less impairment in the absorption of trioctanoin; and 3) after the administration of agents that inhibit protein synthesis, there is markedly impaired absorption of tripalmitin, but the effect on trioctanoin absorption is minimal.

\section{Acknowledgment}

We wish to thank Miss Barbara Jewett for expert technical assistance.

\section{References}

1. Hashim, S. A., H. B. Roholt, and T. B. Van Itallie. Pancreatogenous steatorrhea treated with medium chain triglycerides (abstract). Clin. Res. 1962, 10, 394.

2. Iber, E. L., E. Hardoon, and M. H. Sprague. Use of eight and ten carbon fatty acids as neutral fat in the management of steatorrhea. Clin. Res. 1963, 11,185 .

3. Bush, E. T. General applicability of the channels ratio method of measuring liquid scintillation counting efficiencies. Analyt. Chem. 1963, 35, 1024.

4. Folch, J., M. Lees, and G. H. Sloan Stanley. A simple method for the isolation and purification of total lipides from animal tissues. J. biol. Chem. 1957, 226, 497.

5. Young, C. W., P. F. Robinson, and B. Sacktor. Inhibition of the synthesis of protein in intact animals by acetoxycycloheximide and a metabolic derangement concomitant with this blockade. Biochem. Pharmacol. 1963, 12, 855.

6. Playoust, M. R., and K. J. Isselbacher. Studies on the intestinal absorption and intramucosal lipolysis of a medium chain triglyceride. J. clin. Invest. 1964, 43, 878.

7. Lowry, O. H., N. J. Rosebrough, A. L. Farr, and R. J. Randall. Protein measurement with the Folin phenol reagent. J. biol. Chem. 1951, 193, 265.

8. Isselbacher, K. J., and D. M. Budz. Synthesis of lipoproteins by rat intestinal mucosa. Nature (Lond.) 1963, 200, 364.

9. Sabesin, S. M., and K. J. Isselbacher. Protein synthesis inhibition: mechanism for the production of impaired fat absorption. Science 1965, 147, 1149.

10. Hyams, D. E., S. M. Sabesin, and K. J. Isselbacher. Inhibition of intestinal lipid transport and protein synthesis by ethionine. Fed. Proc. 1965, 24, 671.

11. Hyams, D. E., S. M. Sabesin, N. J. Greenberger, and $\mathrm{K}$. J. Isselbacher. Impairment of protein synthesis and lipid transport in the small intestine by ethionine. Biochim. biophys. Acta (Amst.) 1966, in press.
12. Entressangles, B., L. Paséro, P. Savary, L. Sarda, and P. Desnuelle. Influence de la nature des chaines sur la vitesse de leur hydrolyse par la lipase pancréatique. Bull. Soc. Chim. biol. (Paris) 1961, 43, 581.

13. Desnuelle, P., and P. Savary. Specificity of lipases. J. Lipid Res. 1963, 4, 369.

14. Entressangles, B., P. Savary, M. J. Constantin, and P. Desnuelle. Comportment in vitro et in vivo des chaines courtes situées en position interne dans les triglycérides. Biochim. biophys. Acta (Amst.) 1964, 84, 140.

15. Cohen, B. J. Fat excretion in dogs lacking both bile and pancreatic juice. Proc. Soc. exp. Biol. (N. Y.) 1961, 107, 40.

16. Whitfield, A. G. W., C. W. Crane, J. M. French, and T. J. Bayley. Life without a pancreas. Lancet $1965,1,675$.

17. Tidwell, H. C., and J. M. Johnston. An in vitro study of glyceride absorption. Arch. Biochem. 1960, 89, 79.

18. Senior, J. R., and K. J. Isselbacher. Demonstration of an intestinal monoglyceride lipase: an enzyme with a possible role in the intracellular completion of fat digestion. J. clin. Invest. 1963, 42, 187.

19. Senior, J. R., and K. J. Isselbacher. Activation of long chain fatty acids by rat-gut mucosa. Biochim. biophys. Acta (Amst.) 1960, 44, 399.

20. Ailhaud, G., L. Sarda, and P. Desnuelle. Formation d'hydroxamates d'acides gras a longues chaines par une fraction subcellulaire de muqueuse intestinale. Biochim. biophys. Acta (Amst.) 1962, 59, 261.

21. Clark, B., and G. Hübscher. Monoglyceride transacylase of rat-intestinal mucosa. Biochim. biophys. Acta (Amst.) 1963, 70, 43.

22. Senior, J. R., and K. J. Isselbacher. Direct esterification of monoglycerides with palmityl coenzyme A by intestinal epithelial subcellular fractions. J. biol. Chem. 1962, 237, 1454.

23. Johnston, J. M., and J. L. Brown. The intestinal utilization of doubly-labeled $\alpha$-monopalmitin. Biochim. biophys. Acta (Amst.) 1962, 59, 500.

24. Clark, B., and G. Hübscher. Biosynthesis of glycerides in the mucosa of the small intestine. Nature (Lond.) 1960, 185, 35.

25. Valdivieso, V. D., and A. D. Schwabe. Factors influencing the absorption of a medium chain triglyceride. I. The role of bile in the intraluminal phase of absorption. Gastroenterology 1965, 48, 331.

26. Valdivieso, V. D., and A. D. Schwabe. Factors influencing the absorption of a medium chain triglyceride. II. The role of pancreatic juice in the intraluminal phase of absorption. Gastroenterology 1965, 48, 336.

27. Zurier, R. B., S. A. Hashim, and T. B. Van Itallie. Abolition of cholestyramine-induced steatorrhea by medium chain triglyceride. Fed. Proc. 1965, 24, 375. 